Review Paper

\title{
IS ARISTOTLE'S PLACE REALLY A SURFACE? ON ARISTOTLE'S CONCEPTS OF PLACE IN PHYSICS IV AND CATEGORIES 6
}

\author{
UDC 114 Aristoteles
}

\begin{abstract}
Rita Salis
University of Padua, Department of Philosophy, Sociology, Education and Applied Psychology, Padua, Italy

Abstract. The attribution to Aristotle of the concept of place as bi-dimensional is firstly based on the identification of place with a surface, supposedly carried out by Aristotle in Physics IV. The identity of place with surface would indeed imply that place were missing the third dimension of depth, for the notion of surface was historically related to the notion of plane. Hence, since natural beings are, by definition, moving beings, and they have a three-dimensional extension, the doctrine of the bi-dimensionality of place would imply the impossibility to explain movement. Depth of place also seems to be neglected in another passage, in which Aristotle rejects the third definition of place as an extension between the extremities of the contained body. Scholars who admit the bidimensionality of Aristotelian place emphasize the contrast between the Aristotelian theory of place expounded in Physics and the theory contained in Categories, where the three-dimensionality of place is explicitly admitted. The aim of this paper is to try to convey additional arguments in favour of the three-dimensionality of Aristotelian place, based on the criterion of a more literal reading of the Aristotelian text.
\end{abstract}

Key words: Aristotle, Physics, Place, Extension, Surface, Three-dimensionality.

One of the most controversial questions concerning Aristotle's concept of place is constituted by its seeming identification with a surface. Since place owes its existence to the empirical evidence of the existence of local motion, its identification with a surface, i.e. with only a bi-dimensional extension, would imply that place should comprise just two dimensions. This would then lead to the emergence of the problem that, since natural beings are by definition moving beings, and they have a three-dimensional extension, the identification of place with a surface would lead to the impossibility of motion.

Received May 11, 2018 / Accepted November 1, 2018

Corresponding author: Rita Salis

University of Padua, Department of Philosophy, Sociology, Education and Applied Psychology, Piazza

Capitaniato 3, 35139 Padua, Italy

E-mail: rita.salis@unipd.it 
Aristotelian classical theory of place is expounded in Physics IV. However, the Aristotelian concept of $\tau$ ó $\pi$ o $\varsigma$ also crops up in a number of other works, including the section of Categories dealing with quantity. The relationship between the discussion in Categories and the 'classical' exposition in Physics has troubled Aristotelian commentators from antiquity to the present day ${ }^{1}$. The problem concerns the presentation of place in Categories as a continuous three-dimensional extension, which seems in contrast with the definition of place given in Physics, where the concept of place as a three-dimensional extension would be one of the definitions rejected by Aristotle. Aristotle's discussion on place in Physics IV begins by pointing out that any research on place would not have been possible if there had not been a motion with respect to place ${ }^{2}$. Since, according to Aristotle, natural beings are by definition beings which have within themselves a principle of motion and of stationariness ${ }^{3}$, and Aristotle explicitly admits that a body has three dimensions ${ }^{4}$, if we attribute to him a theory of place as a surface, i.e. as a bi-dimensional extension, we also have to admit the invalidity of Aristotelian physics itself. But let us consider the Aristotelian text.

The Stagirite begins his discussion on $\tau$ ó $\pi$ o $\zeta$ raising the question of the existence or not of place, and affirms that the existence of place is held to be obvious from the fact of mutual replacement, for when water has gone out of a vessel, air is present, and this implies that place is something different from them. Furthermore, the locomotions of the elementary natural bodies show that place is something and that it exerts a certain

\footnotetext{
${ }^{1}$ Although the Ancient Greek commentators apparently show no awareness that there could be a difficulty regarding the way $\tau$ ó $\pi$ o $\zeta$ is presented in Categories on the one hand, and in Physics on the other, their attempt to reconcile the two passages was read as an attempt to reconcile two different concepts (cf. Algra, Keimpe. Concepts of Space in Greek Thought, 136-139 and n. 39, Leiden-New York-Köln: Brill, 1995). According to Ammonius, Simplicius and Philoponus, the Aristotelian conception of $\tau$ ó $\pi$ o $\varsigma$ expounded in Categories was quite compatible with the definition given in Physics. So Ammonius explicitly links the account in Categories to what "is said in the Physics lectures" (cf. Ammonius. In Aristotelis Categorias Commentarium, edidit Adolfus Busse, CAG 4.4, 58, 16-26, Berolini: Reimer, 1895). Then Philoponus quotes the definition of $\tau$ ó $\pi$ o $\varsigma$ given in Physics IV explaining the claim in Categories that place is continuous by saying that "just as the contained, so

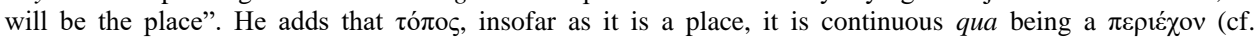
Philoponus [olim Ammonius]. In Aristotelis Categorias Commentarium, edidit Adolfus Busse, CAG 13.1, 87, 7 ff., Berolini: Reimer, 1898). Finally, Simplicius's position is particularly interesting: although the commentator

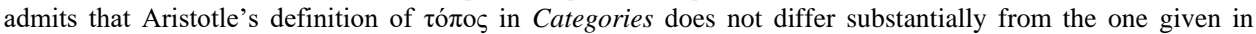
Physics, he also maintains that "if the place is the surface of what surrounds in that it surrounds, and if the surface is continuous, then it is evident that place too is continuous. But he did not employ this proof because it had not yet been determined just what place is. For the question belongs to natural science" (Simplicius. In Aristotelis Categorias Commentarium, edidit Carolus Kalbfleisch, CAG 8, Berolini: Reimer, 1907, 125, 21-29; trans. Barrie Fleet. In Simplicius, On Aristotle Categories 5-6, trans. by Frans A.J. de Haas, and Barrie Fleet, London-New Delhi-New York-Sydney 2001, 104). This passage was taken by H. Mendell as a first hint of

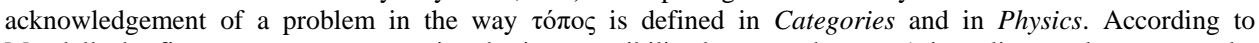
Mendell, the first commentator to notice the incompatibility between the two Aristotelian works seems to be Pacius (cf. Aristotelis Stagiritae Organum, Iulius Pacius recensuit et convertit, Morgiis, 1580, 49 n. e). It is worth noting that Mendell suggests that Aristotle wittingly changes his point of view on place: the implicit view in the Categories would be a view of place as an interval, and this doctrine would be incompatible with the doctrine in Phys. $\Delta$ 1-5 (cf. Henry Mendell. "Topoi on Topos: The Development of Aristotle's Concept of Place". Phronesis 32 (1987): 206-231, esp. 207, n. 5). A definite change in Aristotle's position was recognized by D.J. Furley (cf. David J. Furley. The Greek Commentators' Treatment of Aristotle's Theory of the Continuum. In Norman Kretzmann (ed.), Infinity and Continuity in Ancient and Medieval Thought, Ithaca: Cornell University Press, 1982, 17-36, esp. 19-20). For the other positions in the recent debate, see below.

${ }^{2}$ Cf. Aristot. Phys. IV 1, 208 a 29-32; 4, 211 a 12-13.

${ }^{3}$ Cf. Aristot. Phys. II 1, 192 b 12-14.

${ }^{4}$ Cf. Aristot. Phys. IV 1, 209 a 5-6.
} 
influence, and the theory that the void exists also involves the existence of place, since void is defined as 'place bereft of body'.

After having shown that place exists and that it is something different from bodies which are in it, Aristotle goes on to determine its nature. (1) He excludes that place can be a body asserting that, since place has three dimensions (length, breadth, depth), and every body is limited by these dimensions, if place were a body, there would be two bodies in the same place. (2) Moreover - Aristotle asserts - if body has a place and space, clearly so too have surface and the other limits of body. However, we cannot distinguish a point from its space and, if the place of a body is not different from the point, it will not be different from any of the others and place will not be something different from each of them. (3) Aristotle goes on to say that place cannot be an element or composed of elements, whether these be corporeal or incorporeal. Place, indeed, has size and not body, and the elements of sensible bodies are bodies, while nothing that has size is derived from a combination of intelligible elements. (4) Furthermore, the place cannot be a cause: it is neither a material cause of existents (for there is no body which is composed of it), nor it is a cause as form or definition of things, nor as an end, nor does it move existents. (5) If then place would itself be an existent, it will be in a place: indeed Zeno's difficulty ${ }^{6}$ demands an explanation and if everything that exists has a place, there will be a place of the place and so on ad infinitum. (6) Finally, Aristotle asserts that as every body is in a place, so every place has a body in it. This raises the question of growing things, for place must grow with them, if place is neither less nor greater than they are ${ }^{7}$.

In ch. 2 Aristotle determines that place is neither form nor matter: since it is separable from the thing, it is not the form and, qua containing, it cannot be the matter. The next step in ch. 3 is to see the different senses one thing is said to be in another and to raise the question whether a thing can be in itself, and place can be in a place. Aristotle argues that a thing can be in itself (and a place in a place) not primarily, but in the sense that both preserve their own essence.

In ch. 4 we finally find the definition of 'place'. Aristotle shows that place must be one of just four things: (a) form, (b) or matter, (c) or a kind of extension between the limits of the containing body, (d) or the limit itself, if there is no extension over and above the bulk of the body within it. Aristotle states that (a) it cannot be form, for both are limits but not of the same thing: the form is the limit of the thing, while the place is the limit of the body which contains it. (B) Place cannot even be matter, for the matter is not separable from the thing, nor does it contain it, and both characteristics belong to place. (C) Place is not the extension between the extremities of the thing, which are such that they exist independently, for, if so, in the same place would be an infinity of places, and the place too would be undergoing change, and many places would be coincident. (D) If place is none of the three things, necessarily it is the limit of the containing body ${ }^{8}$.

The main reason of the attribution to Aristotle of the identification of place with a bidimensional extension consists in his objection to (c). The argument against the identification of place with an extension between the extremities of the thing has been mainly interpreted

\footnotetext{
${ }^{5}$ Cf. Aristot. Phys. IV 1208 b 1-27.

${ }^{6}$ Cf. Aristot. Phys. IV 3, 210 b 22-27; 5, 212 b 27-29.

${ }^{7}$ Cf. Aristot. Phys. IV 1, 209 a 2-30.

${ }^{8}$ Cf. Aristot. Phys. IV 4, 211 b 6 ff.
} 
as though it means the denial of the three-dimensionality of place. Let us see if this one is actually the more plausible reading of the passage. In 211 b 19-23 Aristotle says:

If there were an extension which were such as to exist independently and be permanent, there would be an infinity of places in the same thing. For when the water and the air change places, all the portions of the two together will play the same part in the whole which was previously played by all the water in the vessel. ${ }^{9}$

The argument is a reductio ad infinitum. It starts by admitting that there would be an extension which exists as independent and permanent, i.e. as something that exists per se and which is different from the contained body. What kind of extension Aristotle has in mind is indicated more clearly by his description of the third possible definition of place reported just above. There the extension is described as something which subsists per se and as "something over and above the body displaced", because the body contained in it may often be changed while the container remains the same ${ }^{10}$. The theory which Aristotle attacks is therefore based on a precise concept of extension, where, I think, the emphasis is on its independence from what is contained rather than on its three-dimensionality.

Scholars who attack Aristotle for having assigned only the two dimensions of length and breadth to place seem to consider the third definition of place as something over and above the contained body, as excluding the third dimension of depth. Nevertheless, what Aristotle seems to stress is rather the impossibility that place were something independent from the contained thing: if his intent was to deny the identification of place with a threedimensional extension, it would not be important to emphasize the independence of this kind of extension. According to Aristotle, if place were an independent extension, there could not be any movement, for a body without depth cannot have movement and, consequently, it cannot fall into the Aristotelian definition of natural being. Indeed, Aristotle asserts that things that exist by nature are different from things which are not constituted by nature, for the former have within themselves a principle of motion and of stationariness, while artificial bodies, insofar as they are products of art, have no innate impulse to change. Nature is indeed "a source or cause of being moved and of being at rest in that to which it belongs primarily" 11 .

The attribution to Aristotle of the doctrine of the three-dimensionality of place is firstly based on the interpretation of the passage in which Aristotle seems to identify place with a surface. The problem arises because the notion of surface was historically related to the notion of a "plane" ${ }^{12}$. Hence the attribution to Aristotle of the identification of place with a surface adds an argument in favour of the bi-dimensionality of place established in Physics.

\footnotetext{
${ }^{9}$ Aristot. Phys. IV 4, 211 b 19-23 (Robert P. Hardie, and Russell K. Gaye trans. In The Complete Works of Aristotle: The Revised Oxford Translation, edited by Jonathan Barnes, I, 360, Princeton, New Jersey: Princeton University Press, 1984).

${ }^{10}$ Cf. Aristot. Phys. IV 4, 211 b 14-19.

${ }^{11}$ Aristot. Phys. II 1, 192 b 11-22. The thesis that, according to Aristotle, place is a three-dimensional extension is in contrast with that which Philoponus is credited with having acknowledged, against Aristotle, that place possesses all three dimensions.

${ }^{12}$ We find in Euclid the definition of surface as: "that which has length and breadth only" (cf. Heath, Thomas L. trans. Euclid, The Thirteen Books of the Elements. I, Def. 5. Cambridge: Cambridge University Press, 1908). See Lang, Helen S. The Order of Nature in Aristotle's Physics: Place and the Elements, 107. Cambridge: Cambridge University Press, 1998.
} 
This doctrine would be in contrast with what Aristotle says in Categories, where place is described as a three-dimensional extension.

The passage in Physics in which Aristotle would identify place with a surface is the following:

For this reason, too, place is thought ( vessel, i.e. a container of the thing. Further, place is coincident with the thing, for boundaries are coincident with the bounded ${ }^{13}$.

Among scholars who support the agreement between the Aristotelian doctrines of place expounded in Physics and Categories, H.S. Lang is right in criticizing Ross, who affirms that Aristotle here is agreeing with two others of endoxa listed in the beginning of Physics IV 4, i.e. that place is the first container of which it is the place and is not part of the thing, and that the immediate place of a thing is neither less nor greater than the contained body ${ }^{14}$. Lang notes, on the contrary, that in our passage "Aristotle believes that his account explains what others who consider the question think", and that the assertion that place seems to be a surface arises because place is a limit and together with the limited. Lang reports that, according to scholars who attribute to Aristotle the doctrine of the bi-dimensionality of place, given that Aristotle believes that a surface is a limit, the characteristics of a surface must be also those of a limit. Moreover, insofar as the characteristics of surface apply to any limit, they must apply to place too because it is also a limit. Lang's objection is that place is unique, and so possesses characteristics not shared by any other limit, including a surface ${ }^{15}$.

Nevertheless, the meaning of the passage at issue, and consequently the interpretation

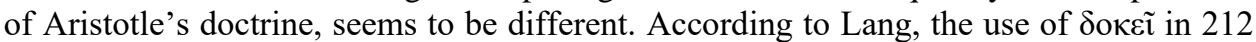
a 28 would suggest that Aristotle is not reporting his own point of view, but what others thought about the question. However, we should pay attention to the fact that this Aristotelian sentence explains the reason why place seems to be a surface and a vessel as

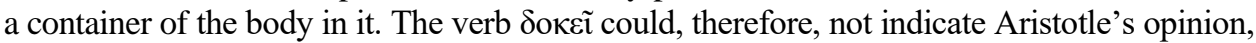
but a hypothetical consequence of the preceding argument, which follows immediately the definition of place as "the innermost motionless limit of the container" 16 . The argument is that, given such a definition of place, the centre of the heaven and the surface of the rotating system are held to be 'down' and 'up', for one is always at rest and the other remains coincident with itself. Hence, since the light is what is naturally carried up, and the heavy what is naturally carried down, the limit towards the centre of the universe, and the centre itself, are down, and the limit in the direction of the outermost part of the universe, and the outermost part itself, are up ${ }^{17}$. This is the reason why, Aristotle goes on to say, it seems that place is a surface. Thus, this conclusion does not appear to indicate how things actually stand, but the reason why things are thought to be in that way. But if this is so, we have to conclude that place is not actually a surface, i.e. a bi-dimensional extension.

The contrast between the doctrine of place elucidated in Physics and what we read in Categories, would arise, for in Cat. 6, which deals with the category of quantity, Aristotle

\footnotetext{
${ }^{13}$ Aristot. Phys. IV 4, 212 a 28-30 (Robert P. Hardie, and Russell K. Gaye trans., 360).

${ }^{14}$ Cf. Aristot. Phys. IV 4, 210 b 34-211 a 1; 211 a 1-2. See Ross, William D. Aristotle's Physics. A Revised Text with Introduction and Commentary, 576. Oxford: Clarendon Press, 1936, repr. Sandpiper Books Ltd., 1998.

${ }^{15}$ See Lang 1998, 104-113.

${ }^{16}$ Aristot. Phys. IV 4, 212 b 20.

${ }^{17}$ Cf. Aristot. Phys. IV 4, 212 b 21-28. See Ross 1936, 376.
} 
distinguishes discrete quantities from continuous quantities, saying that discrete quantities are such that each part of the whole has a relative position to the other parts, while the others have within them no such relation of part to part. As instances of discrete quantities, Aristotle reports number and language; of continuous, lines, surfaces, time and place. The number is a discrete quantity for there is no common limit at which its parts join. For example, two fives make ten, but two fives are separated, i.e. there are not any common boundaries between them. The same is true of language, because it is measured in long and short syllables and there is no common limit at which the syllables join.

Lines and surfaces, indeed, belong to continuous quantities, because there is a common limit at which their parts join: in the case of line the common limit is the point and in the case of the plane it is the line. In a similar way it is possible to find a common limit in the case of a solid, namely either a line or a plane. But continuous quantities are also time - for present is joined to past and future - and place, whose belonging to the continuous is justified by Aristotle as follows:

For the parts of a body occupy some place, and they join together at a common limit (öpov). So the parts of the place occupied by the various parts of the body, themselves join together at the same limit at which the parts of the body do. Thus place also is a continuous quantity, since its parts join together at one common limit ${ }^{18}$.

Here Aristotle justifies the belonging of place to the continuous quantity, saying that the parts of the contained body are joined together in relation to a common limit, and vice versa, the parts of the place which contain the parts of the body join together in relation to the same limit at which the parts of the body are joined. The limit which is common to the parts of the place and the parts of the contained body is the place itself, so the definition of place which Aristotle gives in Categories does not disagree with the definition we find in Physics: in both cases the place is defined as a limit, and the fact that in Physics place has to explain movement, and that in Categories it is described as a continuous quantity for it defines and delimits bodies in it, leads us to conclude in favour of the attribution to Aristotle of the doctrine of the three-dimensionality of place.

Meanwhile, the contrast between the two definitions was underlined by, among others, K. Algra. In support of his thesis, Algra draws on, with the passage just seen, one in which Aristotle comes back to deal with place and raises the question if the category of quantity admits a contrary or not. His answer is negative, and he writes accordingly:

But it is most of all with regard to place that there seems to be contrariety of a quantity. For people regard up as contrary to down - meaning by 'down' the region towards the centre - because the centre is at the greatest distance from the limits of the world. ${ }^{19}$

According to Algra, in this passage, unlike in Physics, where place is defined as "the first unmoved limit of the containing body", ${ }^{20}$ Aristotle would admit the three-dimensionality of place, and from both the passages we have seen it would appear that the concept of place would coincide with one of the definitions of place rejected by Aristotle, i.e. with

\footnotetext{
${ }^{18}$ Aristot. Cat. 6, 5 a 9-14 (Ackrill, John L. trans. In Barnes 1984, 8).

${ }^{19}$ Aristot. Cat. 6, 6 a 11-15 (Ackrill, John L. trans. In Barnes 1984, 10).

${ }^{20}$ Aristot. Phys. IV 4, 212 a 20.
} 
that according to which place would be an independent and permanent extension ${ }^{21}$. Nevertheless, in my view, the point underlined by Algra rather seems the result of a misunderstanding of Aristotle's rejection of the third definition of place as a separated extension. Aristotle's point, indeed, does not seem to be the rejection of the extension as it possesses three dimensions, but rather the rejection of the existence of place as an independent and permanent extension. Aristotle's objection against this definition of place is the result of his denial that more places would occupy the same place, namely of the fact that, if place were to be an independent extension, for each of the parts of the bodies contained in it possesses its own place, there would be an infinity of places in the same place.

Among scholars who supported the agreement between the concepts of place in Physics and in Categories, H. King affirmed that it is not possible to speak about the limit of a container without implying something contained, which he identifies not with a contained body but with a $\delta$ ió $\sigma \tau \eta \mu \alpha \dot{\omega} \varsigma \kappa \varepsilon v o ́ v$, receptive of all body. King's argument is based on Phys. IV 4, 212 a 13-14, which the scholar translates as follows: "Place appears to be not only the boundaries of the vessel, but also the $\delta$ ó $\sigma \tau \eta \mu \alpha$ between regarded as empty"22. According to King, Aristotle would be thinking of place as a receptive $\delta$ ió $\sigma \tau \eta \mu \alpha$ when he calls place 'continuous' in the Categories ${ }^{23}$. Against King's position, Algra notes that in the passage from which King is quoting (Phys. IV 212 a $8 \mathrm{ff}$.), the conclusion of the preceding discussion is contained. At 211 b 6-10 Aristotle was trying to determine if place was (1) form, (2) matter, (3) the extension between the extremities, or (4) the extremities themselves. From 211 b 10 onward, Algra goes on to say, Aristotle considers the four candidates and he would note that the third possibility would derive its plausibility from the fact that we are inclining to think that, in the case of the vessel, there is an extension, which remains when we take away the content of the vessel, e.g. water. Aristotle's answer, Algra asserts rightly, is straightforward: "But this is not" 24 . The passage quoted by King would summarize this procedure, and the rejected candidates would be not wholly extravagant alternatives, but rather would belong to the way we are used to speaking about place. King would not notice the dialectical character of the passage, and his attempt to reconcile Aristotle's concept of place in Physics and Categories should be regarded as unsuccessful.

Algra's interpretation of Phys. IV, 212 a 13-14 and of the context in which the discussion on place is inserted should be accepted. King's attempt to reconcile the concept of place in Categories and Physics, saying that in Physics the three-dimensionality of place is saved for place would be a $\delta i \alpha ́ \sigma \tau \eta \mu \alpha \dot{\omega} \varsigma \kappa \varepsilon v o ́ v$, must be considered invalid, since that is precisely what Aristotle denies. Nevertheless, King is right when he asserts that the limit of the container cannot exist separately from what is contained. The meaning of Aristotle's assertion that the immediate place of a contained body is neither less nor greater than the body $^{25}$ does not indicate, as King believes, the existence of a place which is $\mu \varepsilon \tau \alpha \xi \dot{v} \omega \varsigma$ $\kappa \varepsilon v o ́ v$, but the full coincidence of the thing with the place in which the thing is contained.

The thesis of the three-dimensionality of place was also sustained by A.E. Taylor, who admits that by means of his definition of place as "the first unmoved limit of the containing

\footnotetext{
${ }^{21}$ Cf. Aristot. Phys. IV 4, 211 b 19-23. See Algra 1995, 125-126.

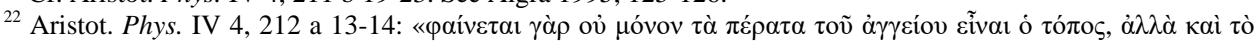

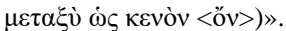

${ }^{23}$ Cf. King, Hugh, R. “Aristotle’s Theory of TОПОГ”. Classical Quarterly 44 (1950): 76-96, esp. 88.

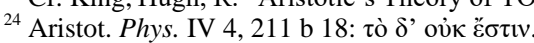

${ }^{25}$ Cf. Aristot. Phys. IV 4, 211 a 2.
} 
body" ${ }^{26}$, Aristotle would seek to determine the greatness of a volume occupied by a body ${ }^{27}$. But Algra recognizes that Taylor's reasons are not the same as King's. Taylor would be aware of the dialectical nature of Aristotle's treatment of the formula which defines place as 'the extension between the limits of the surrounding body'; but, according to Algra, Taylor would be wrong to refer this formula to 'an interval between container and contained'. It would therefore be this concept of place, not the view according to which place is a threedimensional self-subsistent substratum, that Aristotle would rule out in the above- mentioned passage of Physics. Be that as it may, Algra admits that Taylor's thesis, would be vitiated by the fact that the argumentation in Aristotle supports the traditional interpretation of the formula 'that which is between the limits ${ }^{28}$. But the meaning of the passage seems to be the more literal one: Aristotle seems to exclude that place were an interval which is other than the moved bodies ${ }^{29}$, i.e. that is added to the contained things. This does not deny the threedimensionality of place. A more faithful reading of Aristotle's concept of place could lead us to discover a basic agreement of it with the entire Aristotelian natural science.

\section{REFERENCES}

Algra, Keimpe. Concepts of Space in Greek Thought. Leiden-New York-Köln: Brill, 1995.

Ammonius. In Aristotelis Categorias Commentarium, edidit Adolfus Busse, CAG 4.4. Berolini: Reimer, 1895.

Aristotelis Stagiritae Organum. Iulius Pacius recensuit et convertit, Morgiis, 1580.

Aristotle. Categories, trans. by John L. Ackrill. In The Complete Works of Aristotle: The Revised Oxford Translation, edited by Jonathan Barnes, I, 3-24. Princeton, New Jersey: Princeton University Press, 1984.

Aristotle. Physics, trans. by Robert P. Hardie, and K. Gaye Russell. In The Complete Works of Aristotle: The Revised Oxford Translation, edited by Jonathan Barnes, I, 315-446. Princeton, New Jersey: Princeton University Press, 1984.

Euclid. The Thirteen Books of the Elements, trans. by Thomas L. Heath, Cambridge: Cambridge University Press, 1908.

Furley David J. The Greek Commentators' Treatment of Aristotle's Theory of the Continuum. In Infinity and Continuity in Ancient and Medieval Thought, edited by Norman Kretzmann, 17-36. Ithaca: Cornell University Press, 1982.

Jaeger, Werner. Aristotelis Metaphysica recognovit brevique adnotatione critica instruxit, Oxonii: e Typographeo Clarendoniano, 1992.

King, Hugh, R. “Aristotle's Theory of ТОПО乏”. Classical Quarterly 44 (1950): 76-96.

Lang, Helen S. The Order of Nature in Aristotle's Physics: Place and the Elements. Cambridge: Cambridge University Press, 1998.

Mendell, Henry. “Topoi on Topos: The Development of Aristotle's Concept of Place”. Phronesis 32 (1987): 206-231.

Philoponus (olim Ammonius). In Aristotelis Categorias Commentarium, edidit Adolfus Busse, CAG 13.1, Berolini: Reimer, 1898.

Ross, William D. Aristotle's Physics. A Revised Text with Introduction and Commentary. Oxford: Clarendon Press, 1936, repr. Sandpiper Books Ltd., 1998.

Simplicius. In Aristotelis Categorias Commentarium, edidit Carolus Kalbfleisch, CAG 8. Berolini: Reimer, 1907.

Simplicius. On Aristotle Categories 5-6, trans. by Frans A.J. de Haas, and Barrie Fleet. London-New Delhi-New York-Sydney: Bloomsbury, 2001.

Taylor, Alfred E. A Commentary on Plato's Timaeus. Oxford: Clarendon Press, 1928.

\footnotetext{
${ }^{26}$ Aristot. Phys. IV 4, 212 a 20.

${ }^{27}$ Cf. Taylor Alfred E. A Commentary on Plato's Timaeus, Oxford: Clarendon Press, 1928, 668-669.

${ }^{28}$ Cf. Algra 1995, 141-142.

${ }^{29}$ Cf. Aristot. Phys. IV 4, 212 a 11-12.
} 


\section{DA LI JE ARISTOTELOVO MESTO STVARNO POVRŠINA? O ARISTOTELOVOM KONCEPTU MESTA U DELIMA FIZIKA IV I KATEGORIJE 6}

Pripisivanje Aristotelu koncept mesta kao dvodimenzionalnog se prvenstveno zasniva na identifikaciji mesta sa površinom, što je Aristotel navodno $i$ uradio u delu Fizika, tom IV. Izjednačavanje mesta sa površinom bi podrazumevalo da mestu nedostaje treća dimenzija dubine, jer je pojam površine istorijski vezan za pojam ravni. Stoga, pošto su prirodna bića, po definiciji, bića koja mogu da se kreću, i ona imaju trodimenzionalnu ekstenziju, doktrina dvodimenzionalnosti mesta značila bi da je kretanje nemoguće objasniti. Dubina mesta čini se da je zanemarena u drugom odeljku, u kome Aristotel odbacuje treći definiciju mesta kao produžetka između ekstremiteta tela. Naučnici koji priznaju dvodimenzionalnost Aristotelovog mesta naglašavaju kontrast između Aristotelove teorije mesta iznete u delu Fizika i teorija koje su sadržane u delu Kategorije, u kome se postojanje trodimenzionalnosti mesta eksplicitno ističe. Cilj ovog rada je da pokuša da iznese dodatne argumente $u$ korist trodimenzionalnosti Aristotelovog koncepta mesta, na osnovu kriterijuma doslovnog čitanja Aristotelovog teksta.

Ključne reči: Aristotel, fizika, mesto, proširivanje, površina, trodimenzionalnost. 